\title{
The Rate of Asymptomatic Bacteriuria is Similar in Term and Preterm Delivery
}

\section{Kejadian Bakteriuria Asimptomatik tidak Berbeda pada Persalinan Aterm dan Preterm}

\author{
Department of Obstetrics and Gynecology \\ Faculty of Medicine University of Indonesia/ \\ Dr. Cipto Mangunkusumo Hospital \\ Jakarta
}

Surahman Hakim, Gita Pratama, Riska Amelia, Gita N. Hidayah, Huthia Andriyana

\begin{abstract}
Objectives: To show the prevalence of asymptomatic bacteriuria in pregnant women and to find its correlation with preterm labor.

Methods: This research was performed in Dr. Cipto Mangunkusumo Hospital, Jakarta, Indonesia. A total of 78 subjects joined this research. The first group consisted of 39 subjects that were having preterm delivery and the second group consisted of 39 subjects that were having term delivery. Urine analysis and culture were done in both groups. The subject was being considered to have asymptomatic bacteriuria if the urine culture showed a minimum of 100,000 bacteria/ml without any symptoms or signs of urinary tract infection. The number was then analyzed to reveal the correlation of asymptomatic bacteriuria with preterm delivery.

Results: There were a significantly higher number of preterm deliveries in subjects whose age ranged between $15-19$ year-old $(28.20 \%$ vs $12.8 \%$; $\mathrm{p}=0.033$ ). While on the contrary, there was a significantly lower number of preterm delivery in subjects whose age ranged between $30-34$ year-old ( $25.6 \%$ vs $5.12 \%$; $\mathrm{p}=0.020)$.The incidence number of asymptomatic bacteriuria among all subjects is $21.79 \%$. There was no significant difference of asymptomatic bacteriuria between preterm and a term delivery $(23.07 \%$ vs $20.51 \%$; $\mathrm{p}=0.784$ ).

Conclusions: There was no significant difference of asymptomatic bacteriuria between the subject with preterm delivery and term delivery, but the incidence of asymptomatic bacteriuria in pregnant women in this study was quite high, reaching eight times higher than those stated in other study. Thus, routine urine culture screening policy in early pregnancy still cannot be omitted, considering that asymptomatic bacteriuria can lead to pyelonephritis which can cause maternal and fetal morbidity.
\end{abstract}

[Indones J Obstet Gynecol; 37-1: 8-11]

Keywords: asymptomatic bacteriuria, urine analysis, urine culture, preterm delivery

\begin{abstract}
Abstrak
Tujuan: Untuk mengetahui prevalensi bakteriuria asimptomatik pada wanita hamil serta menemukan korelasinya dengan kejadian persalinan preterm.

Metode: Penelitian dilaksanakan di Rumah Sakit Dr. Cipto Mangunkusumo (RSCM), Jakarta. Didapatkan total 78 subjek penelitian dengan 39 subjek mengalami persalinan preterm dan 39 subjek mengalami persalinan aterm. Dilakukan pemeriksaan urinalisis serta biakan dan resistensi kuman pada kedua subjek. Bakteriuria asimptomatik didiagnosis bila didapatkan lebih dari 100.000 bakteri/ml pada biakan urin tanpa adanya gejala klinis infeksi saluran kemih, lalu dinilai angka kejadian bakteriuria asimptomatik dan hubungannya dengan kejadian persalinan preterm.
\end{abstract}

Hasil: Kelompok pasien dengan rentang usia antara 15-19 tahun secara signifikan lebih banyak mengalami persalinan preterm $(28,20 \%$ vs $12,8 \% ; p=0,033)$. Sementara kelompok pasien dengan rentang usia antara 30-34 secara signifikan lebih sedikit mengalami persalinan preterm (25,6\% vs 5,12\%; $p=0,020)$. Angka kejadian bakteriuria asimptomatik dari seluruh subjek adalah 21,79\%. Tidak ditemukan perbedaan bermakna antara kejadian bakteriuria asimptomatik pada persalinan preterm maupun persalinan aterm $(23,07 \%$ vs 20,51\%; $p=0,784)$. Tidak ditemukan korelasi antara poin-poin pemeriksaan urinalisis dengan kejadian bakteriuria asimptomatik maupun persalinan preterm.

Kesimpulan: Tidak ditemukan perbedaan bermakna antara kejadian bakteriuria asimptomatik pada subjek yang mengalami persalinan preterm dengan subjek yang mengalami persalinan aterm. Namun, angka kejadian bakteriuria asimptomatik wanita hamil pada penelitian ini cukup tinggi, sekitar delapan kali lipat dari angka yang dikemukakan pada kepustakaan lain. Dengan demikian pemeriksaan biakan urin rutin terutama pada kehamilan trimester awal tidak dapat disingkirkan, mengingat bakteriuria asimptomatik dapat menyebabkan pyelonefritis yang dapat membahayakan ibu dan janin.

[Maj Obstet Ginekol Indones 2013; 37-1: 8-11]

Kata kunci: bakteriuria asimptomatik, biakan urin, persalinan preterm, urinalisis

Correspondence: Riska Amelia. Department of Obstetrics and Gynecology University of Indonesia. Telephone: 087880787060 Email: dokteriskamelia@yahoo.com

\section{INTRODUCTION}

Preterm delivery is the leading cause of neonatal mortality in both developed and developing countries. World Health Organization reported that one in ten baby who is born every year in the world (around 130 million live birth) is a preterm infant, and most was born in developing countries where the life expectancy is relatively low. ${ }^{2}$ It even reaches 19\% in Indonesia. In the United States of America, it costs ten times higher for preterm infant care comparing to term infant care and took six times longer hospital stay for preterm infants than term infants. ${ }^{2}$ 
Preterm delivery is defined as a labor that started before the pregnancy reach 37 full weeks gestational age. ${ }^{1}$ The etiology are placenta previa, abruptio placenta, intrauterine infection, immune factor such as antiphospholipid syndrome, cervical incompetence, hydramnion, preeclampsia, trauma, fetal congenital anomaly, and idiopathic cause. Several efforts have been done to detect preterm delivery earlier, such as cervical length detection, amniotic fluid metabolites (interleukin-6, glucose, monocyte chemotactic protein-1, C-reactive protein), metabolites in maternal serum, (IL-6, IL-8, tumor necrosis factor a, ferritin, CRP, a-fetoprotein), unconjugated estriol uE3 from saliva, and marker from genital tract (pH, FFN, IL-6, IL-8, TNF$\alpha$ and bacterial vaginosis). ${ }^{2}$ Among all the risk factor for preterm delivery, urinary tract infection or bacteriuria is still unsettled. ${ }^{5-8}$

The incidence of bacteriuria is $10 \%$ of all pregnancy. Asymptomatic bacteriuria is diagnosed if there is a minimum of 100,000 bacteria per mililitre midstream urine without any clinical symptom nor sign of urinary tract infection, such as frequency, urgency, dysuria, pyuria, or hematuria). The gold standard for screening for asymptomatic bacteriuria is growing bacterial cultures of urine samples from women in early pregnancy (12-16 weeks gestation). Socioeconomy status is a significant predictor of asymptomatic bacteriuria, reaching five times higher in low socioeconomy population. ${ }^{7}$ Other risk factors are diabetes mellitus, sickle cell disease, multiparity, history of urinary tract infection, and urinary tract anatomical and functional anomaly. 6,7 Escherichia coli (70$80 \%$ ) is the leading cause of asymptomatic bacteriuria followed by Gram negative bacteria and Streptococcus grup B.6,7

Sheiner et al found that from 199,093 labor, $2.5 \%$ having asymptomatic bacteriuria which related with a higher risk of preterm delivery $(13.3 \%$ and $7.6 \%)$. Other researches also state that bacteriuria is one of the factors that are related with preterm delivery other than age, body weight, parity number, history of miscarriage or still birth, smoking, and bleeding. Around $13 \%$ of untreated women with asymptomatic bacteriuria developed pyelonephritis. Gilstrap et al reported $25 \%$ of women with intrapartum pyelonephritis delivered low birth weight infants compared to $15 \%$ of controls and suggested this was evidence for acute pyelonephritis in pregnancy being associated with preterm labor. In a meta-analysis of 19 studies,
Romero et al reported that women with asymptomatic bacteriuria had a $54 \%$ higher risk of a lowbirth weight infant and twice the risk of a preterm infant compared with non-bacteriuric women.

There are also other research that states the opposite conclusion. Research done by Hundley et al from 1,429 subjects does not found any significant correlation between asymptomatic bacteriuria with preterm delivery. Other smaller research $(400$ subjects) also found that urine culture not a good predictor to preterm delivery.

Therefore, this study aimed to show the prevalence of asymptomatic bacteriuria in pregnant women labor.

\section{METHODS}

This research was performed at the labor ward of Dr. Cipto Mangunkusumo Hospital (RSCM), Jakarta, Indonesia, from November 2011 to June 2012. Minimal sample was counted based on the following formula:

$\mathrm{N}=\left(\mathrm{Z} \alpha^{2}\right)(\mathrm{p})(1-\mathrm{p}) / \mathrm{I} 2$. For $\alpha=0.05, \mathrm{p}=30 \%, \mathrm{I}=$ 0.15 (power $85 \%$ ), the minimal subjects to be acquired were 36 persons. Inclusive criteria were woman with pregnancy less than 37 full weeks gestational age (case group) and 37 full weeks gestational age or more (control group), singleton pregnancy, and willing to participate. The excluding criterias were subjects with symptoms of urinary tract infection, and having other risk factor of preterm delivery such as preterm delivery history, vaginosis symptoms or fluor albus, hypertension, diabetes mellitus, multiple pregnancy, and antepartum hemorrhage (placenta previa, vasa previa, abruptio placenta). There were a total of 78 subjects participating in this study, with 39 subjects were on the case group and 39 subjects were on the control group. Urine specimen from both groups were collected with sterile Nelaton catheter size $12 \mathrm{~F}$ and then undergone urine analysis in clinical pathology laboratory of RSCM and urine culture in microbiology laboratory of RSCM. Asymptomatic bacteriuria was diagnosed if the urine culture shown a minimal of 100,000 bacteria per millilitre urine without any clinical symptoms of urinary tract infection. The data was analysed with SPSS 15 for Windows software. Chi square or Fisher statistic test was done to determine the correlation between asymptomatic bacteriuria and other related factor with preterm delivery. 


\section{RESULTS}

A total of 78 subjects participate this study. There were 39 subjects who have term delivery and 39 subjects who have preterm delivery. The age range of the subjects was quite varied. There was a trend of raising number of subjects having term delivery along with the increasing age and begin to fall again after the age of 35 year old. On the opposite, there was a trend of decreasing number of subjects having preterm delivery along with the increasing age and begin to raise again after the age of 35 year old. Subjects in the age range of 15-19 year-old significantly had higher number of preterm delivery compared to term delivery ( $28.20 \%$ vs $12.8 \%$; $\mathrm{p}=0.033$ ). While subjects in the age range of $30-34$ year-old had significantly higher number of term delivery than preterm delivery $(25.6 \%$ vs $5.12 \%$; $\mathrm{p}=0.020$ ). This results were similar to the study lead by Meis, et al which stated that age were one of the factors that associated with preterm delivery along with maternal body weight, parity, history of miscarriage/still birth, smoking, and vaginal bleeding. ${ }^{8}$

The educational background of both groups showed no significant difference (Table 1). More than half subjects from both groups only have high school diploma ( $56.10 \%$ vs $51.28 \%$ ), followed by junior high school graduates $(25.64 \%$ vs $35.90 \%)$ and elementary school graduates $(10.26 \%$ vs $10.26 \%)$.

Table 1. Educational background of subjects

\begin{tabular}{lccc}
\hline \hline \multirow{2}{*}{ Education } & \multicolumn{2}{c}{ Condition } & Total \\
\cline { 2 - 3 } & Term & Preterm & \\
\hline Illiterate & 1 & 0 & 1 \\
Elementary & 4 & 4 & 8 \\
Junior high & 10 & 14 & 24 \\
High school & 22 & 20 & 42 \\
Bachelor & 1 & 1 & 2 \\
Undergraduate & 1 & 0 & 1 \\
\hline \multicolumn{1}{c}{ Total } & 39 & 39 & 78 \\
\hline \hline
\end{tabular}

The occupational background distribution in both groups seems quite similar (Table 2). The majority of subjects worked as housewives $(74,36 \%$ vs $76,92 \%)$.
Table 2. Occupational background of subjects

\begin{tabular}{lccc}
\hline \hline \multirow{2}{*}{ Occupation } & \multicolumn{2}{c}{ Condition } & Total \\
\cline { 2 - 3 } & Term & Preterm & \\
\hline Student & 1 & 2 & 3 \\
Housewife & 29 & 30 & 59 \\
House maid & 2 & 3 & 5 \\
Waitress & 2 & 0 & 2 \\
Clerk & 3 & 4 & 7 \\
Nurse & 1 & 0 & 1 \\
Teacher & 1 & 0 & 1 \\
\hline \multicolumn{1}{c}{ Total } & 39 & 39 & 78 \\
\hline \hline
\end{tabular}

Urine culture data shown a total of 17 subjects had bacteriuria, 9 of them were on term delivery group $(23.07 \%)$ and 8 of them were on preterm delivery group (20.51\%). The total incidence of asymptomatic bacteriuria in all subjects was $21.79 \%$ (Table 3). This number was much more higher than those stated in the study by Sheiner et al, which was $2.5 \%$ of all pregnant women having asymptomatic bacteriuria. This was probably caused by lower socioeconomy status in all of the subjects, which was a significant predictor of asymptomatic bacteriuria. $^{7}$

Nevertheless, there was no statistically significant difference of asymptomatic bacteriuria incidence in both groups $(\mathrm{p}=0.784)$. The negative correlation was similar with the study of 1.429 subjects lead by Hundley et al.

Table 3. Asymptomatic bacteriuria in all subjects

\begin{tabular}{crcc}
\hline \hline $\begin{array}{c}\text { Urine } \\
\text { Culture } \\
\text { (per ml) }\end{array}$ & \multicolumn{2}{c}{ Condition } & Total \\
\cline { 2 - 3 } & Term & Preterm & \\
\hline Bacteria $<100,000$ & 30 & 31 & 61 \\
Bacteria $>100,000$ & 9 & 8 & 17 \\
\hline Total & 39 & 39 & 78 \\
\hline \hline
\end{tabular}

There were 20 microorganism species that cause positive bacteriuria (more than 100,000 colony $/ \mathrm{ml}$ ) in subjects of this study. One specimen might contain more than one species. Acinetobacter $s p$. was the leading cause of bacteriuria in all sub- 
jects (25\%), followed by Escherichia coli, Staphylococcus epidermidis, and Klebsiella oxytoca (Table 4).

Table 4. Bacteriuria causative microorganism

\begin{tabular}{lc}
\hline \multicolumn{1}{c}{ Species } & Number \\
\hline Acinetobacter sp & 5 \\
Escherichia coli & 4 \\
Staphylococcus epidermidis & 3 \\
Klebsiella oxytoca & 2 \\
Enterococcus sp. & 1 \\
Klebsiella pneumoniae & 1 \\
Staphylococcus aureus & 1 \\
Streptococcus alfahemolytic & 1 \\
Streptococcus betahemolytic group B & 1 \\
Streptococcus betahemolytic group C & 1 \\
\hline \multicolumn{1}{c}{ Total } & 20 \\
\hline \hline
\end{tabular}

On the other hand, urine analysis failed to show any bacteria from all the subjects. All specimens were shown negative bacteria in urinary sediment analysis. This result opposed the urine culture data. Other marker of urinary tract infection such as nitrite and leukocyte esterase, did not only shown insignificant difference in both group, but also the fact that it is unrelated with bacteriuria.

Other urine analysis marker, such as urine color and transparency, urine sediment (leukocyte, erythrocyte, cylinder, epithelial, and crystal), $\mathrm{pH}$, protein, bilirubin, glucose, ketone, blood/Hb, or urobilinogen, had no significant difference in both groups. This showed that urine analysis cannot be used to predict asymptomatic bacteriuria in pregnant women.

\section{CONCLUSION}

This study found asymptomatic bacteriuria in $51 \%$ subjects who had preterm delivery. But a quite similar number was also found in subjects with term delivery (23.07\%). From this data we can conclude that urine analysis and culture cannot be used to predict preterm delivery. Therefore, urine analysis and culture screening in pregnant women were considered to be unnecessary if aimed to prevent preterm delivery.

However, the total incidence of asymptomatic bacteriuria in pregnancy from this study was far higher than the average number. This was a remarkable finding, since asymptomatic bacteriuria can lead to pyelonephritis, which has a positive association not only with preterm delivery but also to maternal morbidity and low birth weight infants. Therefore, urine culture screening in early pregnancy as a gold standard of diagnosing asymptomatic bacteriuria in pregnancy is still cannot be omitted.

\section{REFERENCES}

1. Leveno KJ CF, Alexander JM, Bloom SL, Casey BM, Dashe JS, Sheffield JS, Roberts SW, ed. Premature birth: definitions, consequences and causes. $22^{\text {nd }}$ ed. New York: The McGrawHill Companies 2007.

2. Wax JR, Cartin A, Pinette MG. Biophysical and biochemical screening for the risk of prematur labor. Clin Lab Med. 2010; 30:693-707.

3. Survei Demografi Kesehatan Indonesia (SDKI). Angka kematian Neonatus, Bayi dan Balita tahun 2007.

4. Kementerian Kesehatan Direktorat Penelitian dan Pengembangan. Riset Kesehatan Dasar (Riskesdas). Uploaded from www.litbang.depkes.go.id/riskesdas/index.htm. Accessed at $16^{\text {th }}$ December, 2009.

5. Ovalle A, Levancini M. Urinary tract infections in pregnancy. Curr Opin Urol. 2001; 11:55-9.

6. Schnarr J, Smaill F. Asymptomatic bacteriuria and symptomatic urinary tract infections in pregnancy. Eur J Clin Invest. 2008; 38 Suppl 2:50-7.

7. Macejko AM, Schaeffer AJ. Asymptomatic bacteriuria and symptomatic urinary tract infections during pregnancy. Urol Clin North Am. 2007; 34:35-42.

8. Meis PJ, Michielutte R, Peters TJ, et al. Factors associated with prematur birth in Cardiff, Wales. II. Indicated and spontaneous prematur birth. Am J Obstet Gynecol. 1995; 173:597-602.

9. Campbell-Brown M, McFadyen IR, Seal DV, et al: Is screening for bacteriuria in pregnancy worth while? Br Med J Clin Res Ed 1987; 294: 1579-82

10. Gilstrap LC, Leveno KJ, Cunningham FG, et al: Renal infection and pregnancy outcome. Am J Obstet Gynecol 1981; 141: 709-16.

11. Romero R, Oyarzun E, Mazor M, et al. Meta-analysis of the relationship between asymptomatic bacteriuria and preterm delivery/low birth weight. Obstet Gynecol 1989; 73: 576-82 